\title{
Sarotrocercus oblitus - Small arthropod with great impact on the understanding of arthropod evolution?
}

\author{
JoACHIM T. HAUG, ANDREAS MAAS, CAROLIN HAUG \& Dieter WALOSZEK
}

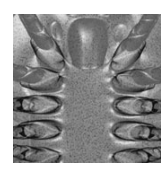

\begin{abstract}
Sarotrocercus oblitus is a small arthropod from the Cambrian Burgess Shale. It was originally described with a short head with only two appendage-bearing segments (the first appendage being limb-shaped), a short trunk of nine segments and lamellate trunk limbs. This rather "unusual" morphology inspired various authors to propose evolutionary scenarios concerning segmentation and appendages. The head of S. oblitus served also for scenarios about the evolution of the arthropod head, because it seemed to document the evolutionary step between the level of Arthropoda sensu stricto (head with one appendage-bearing segment) and that of Euarthropoda (head comprising four appendage-bearing segments). Here we report that the morphology of S. oblitus differs in several significant aspects from its original description, e.g., in the composition of the head, number of trunk segments, and appendage morphology. In consequence, many earlier assumptions based on the original description must be rejected. Although the material consists of only seven individuals, ontogenetic variation of the number of trunk segments was observed, pointing to, at least, two developmental stages. Therefore, $S$. oblitus is morphologically less different from other Cambrian arthropods than previously thought, but possesses a head with three appendage-bearing segments and lacks a prominent antenn(ul)a. These characters point to a position of S. oblitus inside Arthropoda s. str., deriving from the lineage towards Euarthropoda. The morphology also indicates a special life style, e.g., by the presence of large, stalked eyes, apparently in convergence to one of the Cambrian "Orsten" crustacean stem-lineage derivatives, Henningsmoenicaris scutula. - Key words: Burgess Shale, Cambrian, Arthropoda sensu stricto, Euarthropoda, ontogeny.
\end{abstract}

HAUG, J.T., MAAS, A., HAUG, C. \& WALOSZEK, D. 2011. Sarotrocercus oblitus - Small arthropod with great impact on the understanding of arthropod evolution? Bulletin of Geosciences 86(4), 725-736 (5 figures). Czech Geological Survey, Prague. ISSN 1214-1119. Manuscript received May 16, 2011; accepted in revised form September 5, 2011; published online November 1, 2011; issued November 16, 2011.

Joachim T. Haug \& Carolin Haug, Department of Geology and Geophysics, Yale University, 210 Whitney Avenue, New Haven, CT 06511, USA; joachim_haug@gmx.de, joachim.haug@yale.edu・Andreas Maas \& Dieter Waloszek, Biosystematic Documentation, University of Ulm, Helmholtzstr. 20, 89081 Ulm, Germany

Evolution of Arthropoda is a vivid field of paleo- and neozoological research. Especially the early steps along the evolutionary lineage of the taxon are still under debate. Waloszek and co-workers (Maas et al. 2004; Waloszek et al. 2005, 2007) introduced a differentiated view on the distinct evolutionary levels within Arthropoda sensu lato. This taxon comprises Onychophora, the paraphyletic lobopodians, Tardigrada, Pentastomida, and Arthropoda sensu stricto (the sclerotised arthropods); Euarthropoda is an in-group of Arthropoda sensu stricto. Much of the ground pattern morphology of Arthropoda sensu stricto is especially represented by Shankouia zhenghei Chen, Wang, Maas \& Waloszek in Waloszek et al. (2005) from the Chinese Chengjiang Lagerstätte. S. zhenghei possesses a head comprising only two segments, the ocular segment (with a separate small tergite) and the subsequent segment bearing a pair of simple, uniramous appendages (the antennulae, often referred to as "antennae"). Additionally, it is charac- terized by a posteriorly and laterally expanded head shield originating only from the first limb-bearing segment and covering several of the anterior trunk segments. All post-antennal limbs are trunk limbs, which are all similar in morphology. Each limb comprises a rod-like limb stem (almost circular in cross section), with about 20 ringlets articulating against each other by pivot joints anteriorly and posteriorly along the main axis. Laterally a flap-like exopod is attached to the stem. The appendages, referred to as arthropodium (Haug et al. accepted a) appear to lack any setation, including the rounded tip. $S$. zhenghei is generally accepted as a basal sclerotised arthropod, although opinions may differ in certain detail (Waloszek et al. 2005, Scholtz \& Edgecombe 2006, Budd 2008).

In the ground pattern of Euarthropoda (sensu Walossek 1999) the head has elongated and comprises the ocular segment, the segment of the antennula, and three more appendage-bearing segments, i.e., the head consists now of 
five segments. Additionally, the still serial limbs have become differentiated further. The most proximal element of the limb (euarthropodium; Haug et al. accepted a) is a sclerotised, rigid anterior-posteriorly flattened structure, the basipod resulting in an elongation of the limbs in median-lateral axis. The basipod is sub-square to triangular in anterior/posterior view with a straight median edge equipped with an armament of spines involved in feeding. Medio-distally the elongated, rod-shaped endopod arises (almost as circular in cross section as the earlier limb type) from the sloping lateral edge, probably comprising eight or nine cylindrical elements. These elements are proximodistally drawn out into small enditic protrusions carrying spines or setae; the distal rounded tip carries at least one spine or seta. Latero-distally the paddle-shaped exopod articulates with the sloping edge of the basipod. The exopod is fringed with setae. Whether the exopod is subdivided into a proximal triangular element and the true paddle as in the "stem chelicerate" Leanchoilia illecebrosa (Hou, 1987) and the "stem crustaceans" Oelandocaris oelandica Müller, 1983 and Henningsmoenicaris scutula (Walossek \& Müller, 1990) is still unclear (Liu et al. 2007, Stein et al. 2008, Haug et al. 2010). An arthrodial membrane with several folds permits a flexible insertion of the limb at the body.

As the ground pattern of Euarthropoda is characterized by such a high number of autapomorphic characters, it is likely that these are in fact the result of a longer-lasting and step-wise acquisition including several species-split events. One taxon that was already supposed to fit "right in between" is Canadaspis (Maas et al. 2004), but this has to be further investigated and just may mark a starting point for future research also on more of these early arthropod taxa. In either way, the search for species that have already developed some, but not (yet) all characters of Euarthropoda will greatly facilitate a more differentiated resolution of the early evolution of the sclerotized arthropods than what has been established until now.

One candidate for representing such an "in between" taxon is, in our view, Sarotrocercus oblitus Whittington, 1981. Based on its original description, S. oblitus has a short head, comprising the ocular segment and only two appendage-bearing segments. Additionally, it should have a rather leg-like first appendage (the antennula). Re-investigation especially of this species was considered desirable in any case because of the following reasons. Whittington (1981) described S. oblitus based on nine specimens (in fact only seven, as there are two part/counterpart pairs), which are rather poorly preserved compared to other fossils from the famous Burgess Shale Lagerstätte. Therefore, Whittington kept the description rather quite short, compared to his otherwise usually detailed and comprehensive style, and also provided only a rather sketchy reconstruction. Nevertheless, $S$. oblitus has gained a lot of attention in special literature since its original designation (compare the synonymy list in Results part). It was also used for discussing the evolution of limb development (e.g., Schram \& Koenemann 2001, Boxshall 2004), as Whittington (1981) had described the trunk limbs as lacking endopods, but also the evolution of body tagmosis (Minelli 2001) because of its supposed short head. Fryer (1998) even named S. oblitus the "most primitive arthropod".

Re-investigation of $S$. oblitus was also considered very promising as new photographic techniques have been developed since Whittington's early investigation that greatly enhance the possibility of identifying even small details on fossils from the Burgess Shale (e.g., Bengtson 2000). In consequence, our re-investigation aims at (a) documenting the fossils with new photographic techniques and (b) evaluating whether Sarotrocercus oblitus could mark an additional evolutionary level "between" Arthropoda sensu stricto and Euarthropoda, or if it represents a further in-group taxon of Euarthropoda.

\section{Material and methods}

The complete material of Sarotrocerus oblitus present in the collection of the National Museum of Natural History of the Smithsonian Institution, Washington, D.C., USA was re-investigated. The material comprises nine specimens including two pairs of part and counterpart, in total the fossil remains of seven individuals (USNM 275539 [counterpart 272143], 272171 (holotype) [counterpart 144890], 144893, 272009, 272133, 272151, 272194). All specimens were documented under three different light settings: low-angle side light, almost vertical reflected light and polarized light. Best results were achieved using polarized light, but some details were only observable under almost vertical reflected light. For inspection a Nikon SMZ-U stereo-microscope was used. For photographs a ScopeTek DCM 510 ocular camera was directly mounted onto the stereo microscope. As under higher magnifications the rather low relief of the specimens is already high enough to cause a diffuse picture, several images of the same area were taken in different focal planes and later fused with the free computer program CombineZM. Tentative reconstructions of the outer morphologies of the investigated species were produced as 3D models using the open source software Blender.

\section{Systematic palaeontology}

Arthropoda sensu lato (sensu Maas et al., 2004)

Arthropoda sensu stricto (sensu Maas et al., 2004)

\section{Genus Sarotrocercus Whittington, 1981}

* 1981 Sarotrocercus gen. nov. - Whittington, p. 347. 


\section{Sarotrocercus oblitus Whittington, 1981}

Remark. - We recommend to revise the species name to S. oblitus, as the ending -us in Sarotrocercus suggests that it is masculine. Unfortunately, Whittington (1981) did not explain the derivation of the name in the original species description.

v 1975 Molaria spinifera. - Simonetta \& Delle Cave, pl. XIX, fig. 9, pl. XX, fig. 1 [sic].

* 1981 Sarotrocercus oblita gen. nov., sp. nov. - Whittington, pp. 330, 332, 334, 347; figs 89 (USNM 144893), 90 (USNM 272151), 91 (USNM 272151), 92 (USNM 144893), 94 (USNM 144893, drawing), 95 (USNM 272151, drawing), 96 (USNM 275539), 97 (USNM 272194, drawing), 98 (USNM 144890), 99 (USNM 275539), 100 (USNM 272143), 101, 102 (USNM 272194), 103-105 (USNM 272171), 106 (USNM 275539), 107, 108 (USNM 144890), 109 (USNM 272009), 131.

1991a Sarotrocercus. - Gould, pp. 198, 200; fig. 3.49 [sic].

1991b Sarotrocercus. - Gould, p. 416 [sic].

1992 Sarotrocercus. - Briggs \& Fortey, pp. 364, 368; tab. 10.1; fig. 10.3 [sic].

1994 Sarotrocercus. - Gould, fig. 4.8 [sic].

v 1994 Sarotrocercus oblita Whittington, 1981b. - Briggs et al., p. 185; figs 147 (USNM 272171), 148.

1994 Sarotrocercus. - Wills et al., figs 7A-C, 8, 11; appendix 1 [sic].

1995 Sarotrocercus. - Wills et al., fig. 1A [sic].

1998 Sarotrocercus. - Wills et al., p. 62, figs 6.2, 6.5.

1998 Sarotrocercus. - Dewel \& Dewel, fig. 10.4 [sic].

1998 Sarotrocercus. - Fryer, p. 27 [sic].

1998 Sarotrocercus. - Delle Cave et al., p. 27 [sic].

1999 Sarotrocercus. - Briggs \& Collins, p. 974 [sic].

1999 Sarotrocercus oblita. - Fryer, pp. 6, 9; fig. 6.

1999 Sarotrocercus. - Gould, fig. 1.3 [sic].

2001 Sarotrocercus. - Barnes et al., fig. 2.10g [sic].

2001 Sarotrocercus. - Budd, p. 414 [sic].

2001 Sarotrocercus. - Burzin et al., fig. 10.1 [sic].

2001 Sarotrocercus. - Minelli, p. 518 [sic].

2001 Sarotrocercus oblita. - Schram \& Koenemann, p. 346.

2002 Sarotrocercus. - Sutton et al., fig. 5 [sic].

2002 Sarotrocercus. - Selfa \& Pujade-Villar, p. 150; fig. 7.9G [sic].

2004 Sarotrocercus oblita. - Boxshall, p. 286.

2004 Sarotrocercus. - Cotton \& Braddy, pp. 170, 171; fig. 2 [sic].

2006 Sarotrocercus Whittington, 1981. - Van Roy, p. 333 [sic].

2007 Sarotrocercus. - Barton et al., fig. 10.15 (12) [sic]

2008 Sarotrocercus oblita. - Caron \& Jackson, tab. 1; fig. 11; appendix B, C, D, F.

2009 Sarotrocercus. - Lin 2009, p. 3 [sic].
Emended diagnosis. - (Remark: this diagnosis is based on the oldest known ontogenetic stage, yet it is unclear whether this represents the adult.) Small arthropod with an oval, convex body divided into head and trunk, caudally ending in a telson. Head dorsally forming cephalic shield, freely overhanging first trunk segment. Trunk segments dorsally forming tergites. Trunk with eleven trunk segments in the oldest known stage. Telson is elongated into a spine with nine spinules terminally. Large stalked eye projecting from beneath anterolateral margin of cephalic shield. Head with probably three pairs of appendages. Appendages two and three biramous, inner ramus with at least four articles, proximal ones drawn out medio-distally into spines. Exopod of appendages two and three as small paddles with three setae distally. Exopods of trunk limbs equipped with about twelve setae along the disto-lateral margin.

Description. - Small arthropod, largest known specimens only slightly more than ten millimeters long (Figs 1, 2). Two growth stages can be distinguished which differ only slightly. Therefore, they are described here together and differences are pointed out where present. The head probably comprises three appendage-bearing segments, its dorsal cuticle forming a shield (Fig. 1E). The trunk comprises eleven segments (in the presumed adult stage, named here stage II; Fig. 1A-G) and a long terminal spine considered to represent the non-segmental telson (Fig. 1A-E, G-I). The caudal end of the telson spine fans out into nine spinules (Fig. 3F). In an apparently earlier developmental stage (named stage I; Fig. 1H, I) the trunk comprises only ten segments plus the telson. It remains unclear whether eleven is the final number of trunk segments, or if there are later developmental stages with even more trunk segments.

The head shield has a sub-rectangular shape in dorsal view. It is slightly wider than long, about $4.9 \mathrm{~mm}$ wide and $4.3 \mathrm{~mm}$ long in growth stage II (Fig. 1C), and its relative wideness is even more prominent in stage I with about $4.9 \mathrm{~mm}$ in width and $3.3 \mathrm{~mm}$ in length (Fig. $1 \mathrm{H})$. The anterior margin of the shield is rounded, the posterior margin is straight, both in dorsal view. The shield is devoid of ornamentation including marginal spines (Fig. 1G). On the ventral side of the head a hypostome is most likely present, indicated by impressions on the dorsal area (Fig. 1E) and some faint traces ventrally (Fig. 1A, B). A pair of bulbous compound eyes on stalks inserts ventrally, probably anterior to the supposed hypostome (Fig. 1C, E, H), and protrudes antero-laterally from the head shield. The eyes without the stalks are $1.2-1.5 \mathrm{~mm}$ long in proximo-distal axis and $0.7-0.8 \mathrm{~mm}$ wide. Facets are not visible.

Uniramous anterior appendages in the fashion of antenn(ul)ae could not be discovered on any specimen. Instead, behind the eyes insert two pairs of apparently biramous, subequal cephalic appendages (Fig. 1E, 3A, B). Of the inner ramus, possibly the endopod, four distal articles 
can be assured, as these lie outside the shield margin (Fig. 3A, B). The proximal of these four articles lies still far from the body midline, suggesting the presence of a further proximal part of the limb, which is concealed by the shield. It is unclear, how this further proximal part of the limb was organised: it may have been (1) a rigid basipod, (2) a basipod plus additional endopodal articles, or (3) only such articles were present down to the limb insertion. In the latter case the term endopod would be inappropriate, but this limb part would be termed the limb stem ( $c f$. Waloszek et al. 2005, 2007; Haug et al. accepted a). Yet, based on the present material the true morphology cannot be determined. For practical reasons, the visible four elements are termed endopod in our description below despite the known uncertainties. A small lateral paddle with three distal setae, the exopod, also extends from the shield margin. It may articulate to the limb stem or the basipod (Fig. 3A, B). The exact position of this articulation is unclear, but was most likely significantly closer to the body midline than the shield margin.

The articles of the endopod are numbered consecutively from proximal to distal (see Fig. 3A). Article one is tubular and about as long (in proximo-distal axis) as wide (= "in diameter"), about $0.5 \mathrm{~mm}$. Medio-distally it is drawn out into a small enditic protrusion continuing into a small spine. Article two is slightly smaller than one, otherwise similar. Article three is significantly slenderer than the preceding articles, also about $0.5 \mathrm{~mm}$ in length, but only $0.3 \mathrm{~mm}$ in diameter. Like the preceding articles it is drawn out into a small enditic protrusion medio-distally. The terminal article (number four) is even more slender, measuring about $0.5 \mathrm{~mm}$ in length, but only $0.25 \mathrm{~mm}$ in diameter. It is not drawn out into an enditic protrusion, but bears two setae distally, about $0.3 \mathrm{~mm}$ in length. The exopod is a tiny paddle about $0.6 \mathrm{~mm}$ in length and less than $0.2 \mathrm{~mm}$ in width. Three setae arise from its distal margin (Fig. 3A, B).

The trunk ( ca 5.3-7 mm long) comprises 11 (in stage II) or ten trunk segments (stage I), having a rectangular shape in dorsal view. Each tergite is about $0.6 \mathrm{~mm}$ long. The shield covers the first trunk segment freely. Therefore, this segment is only visible as an impression below the shield (e.g., Fig. 1G) or in specimens, in which the shield is detached (Fig. 1F). Based on the positions of the limbs the tergites extend laterally into tergopleurae (Fig. 1B).

The anterior segments have tergites with straight anterior and posterior margins (Fig. 1G). The tergites are slightly arched dorsally, indicating a possible dorso-ventral body extension of ca. 30 percent of the maximum body width. Due to this arching the tergites may appear to have rounded anterior and posterior margins, when the embedding was oblique (Fig. 1F). The tergite of the first segment is slightly narrower than the head shield, the next three tergites are wider than the preceding one and more or less as wide as the head shield. On the more posterior tergites, from segment four or five onward, the lateral areas, i.e., the tergopleurae, are curved increasingly more posteriorly while the median part of the tergites still has straight anterior and posterior margins. The width decreases progressively, i.e., segment five is about 10 percent narrower than segment four, and so on. The tergite of segment eight (in stage I) respectively nine (in stage II) is curved far enough to call it crescent-shaped. The posterior edges of these tergites appear to be drawn out into short pleural spines (Fig. 3D, E). Segment nine (in stage I) respectively ten (in stage II) is also significantly smaller than the preceding segments. It has only about two third of the width of the preceding tergite. Tergite nine/ten is also crescentshaped and armed with short pleural spines. Segment ten (in stage I), respectively eleven (in stage II) is even smaller. It is about fifty percent of the preceding segment in width. Its tergite is further bent in dorsal view, closely resembling a C. It extends posteriorly into short pleural spines (Fig. 3D, E).

Only few ventral details of the trunk can be observed on the material at hand. Remains of the trunk limbs, present in specimen USNM 272143, are interpreted as inwardly folded exopods. These are leaf-shaped, about $1.4 \mathrm{~mm}$ in presumed proximal-distal axis, and about $0.8 \mathrm{~mm}$ in presumed median-lateral axis. About seven setae arise from the presumed lateral margin, but, based on the available space on this edge, there might have been about one dozen of such setae originally (Fig. 3C). Other details of the trunk limbs remain unknown. It remains also unclear whether the very small posterior trunk segments bore limbs or were apodous. The spine-like last trunk portion, interpreted as the telson, articulates against the last trunk segment, between the pleural spines in dorsal view, and extends caudally. It is slightly shorter then the entire segmented part of the trunk and decreases in diameter from about $0.35 \mathrm{~mm}$ to about $0.2 \mathrm{~mm}$ distally. The distal end is equipped with nine thin spines (spinules) of less than $0.1 \mathrm{~mm}$ diameter and up to $0.8 \mathrm{~mm}$ in length. From proximal to distal six spinules emerge in two sets of three from the sides of the tail spine, becoming progressively longer (Fig. 3F). The distal three spinules are the longest of the set and form a trident in medio-lateral plane. An anal opening could not be validated.

\section{Discussion}

\section{Reconstruction of Sarotrocercus oblitus}

The reconstruction of Sarotrocercus oblitus reflects the incomplete knowledge of many details. Nevertheless, we can amend the original reconstruction given by Whittington (1981) in various aspects (Fig. 4). The new reconstruction gives, in our view, also a more plausible view of the 


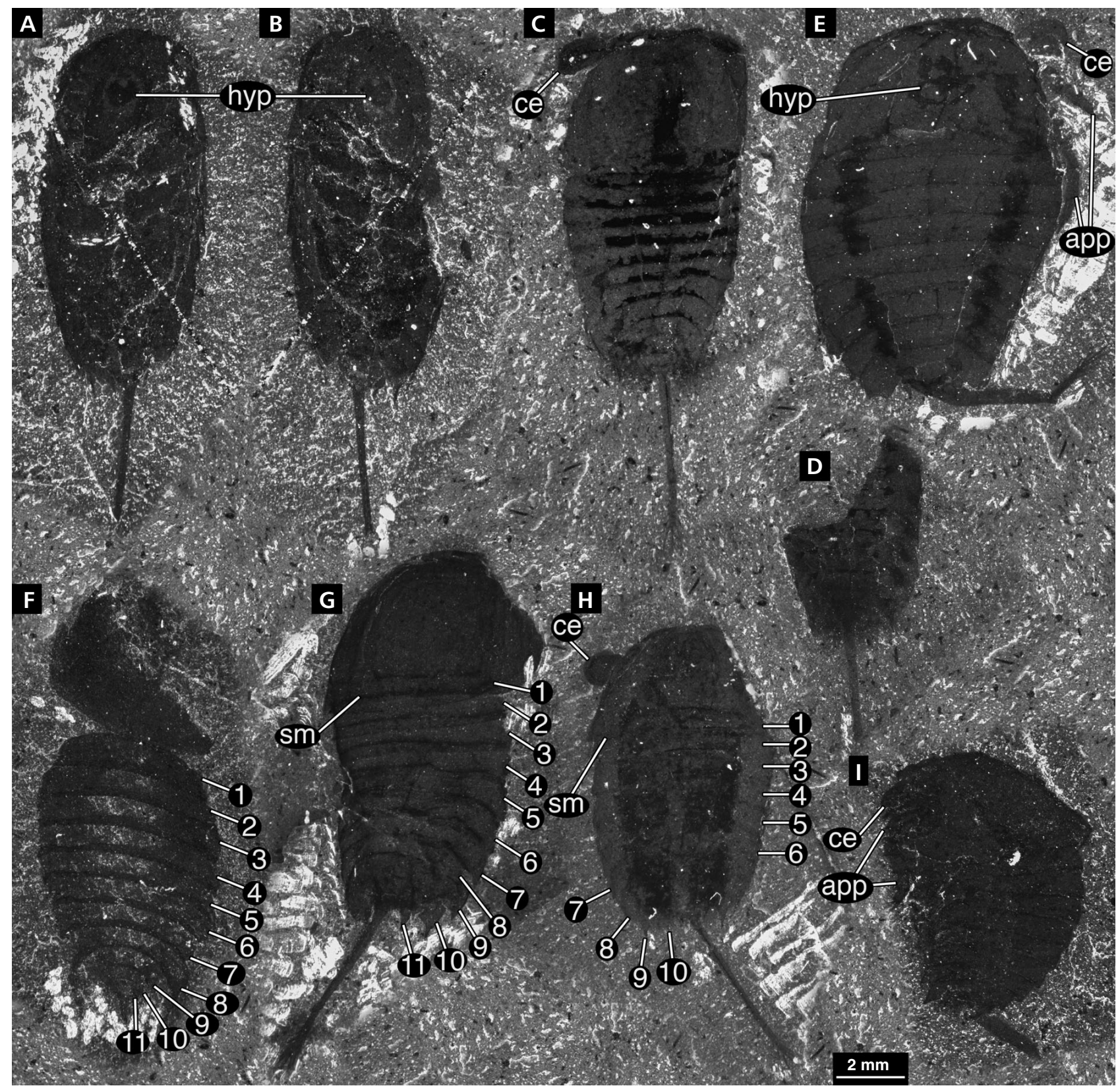

Figure 1. The complete original material of Sarotrocercus oblitus Whittington, 1981 under polarized light. All specimens are depicted in the same scale to demonstrate their relative sizes. All specimens arranged on a virtual "shale matrix" to enhance comparability. $\bullet A-G-$ larger specimens (stage II) with 11 trunk segments, H, I - smaller specimens (stage I) with ten trunk segments. • A - USNM 275539. B - USNM 272143 (counterpart of A). C - USNM 272171 (holotype). D - USNM 144890 (counterpart of C). E - USNM 272194. F - USNM 272133. G - USNM 272099. H - USNM 144893. I - USNM 272151. Abbreviations: 1-11 - trunk segment number X; app - appendage; ce - compound eye; hyp - hypostome; sm - shield margin.

species and corrects certain aspects from Whittington's original description. This was not least possible due to the application of polarized light photography (Bengtson 2000), which proved to be a powerful tool of observation that was not yet available for Whittington's (1981) original investigation.

To facilitate direct comparison of our findings with the original interpretation of Whittington (1981), we applied in the following the same numerals as in Whittington's description. As only certain points are in need to be discussed, these numerals are discontinuous. We cannot contribute new details concerning Whittington's (1981) points (i) and (iv).

(ii of Whittington 1981) Whittington interpreted dark bands on the posterior of the head shield and tergites as indications of articulating flanges. Not all specimens have 


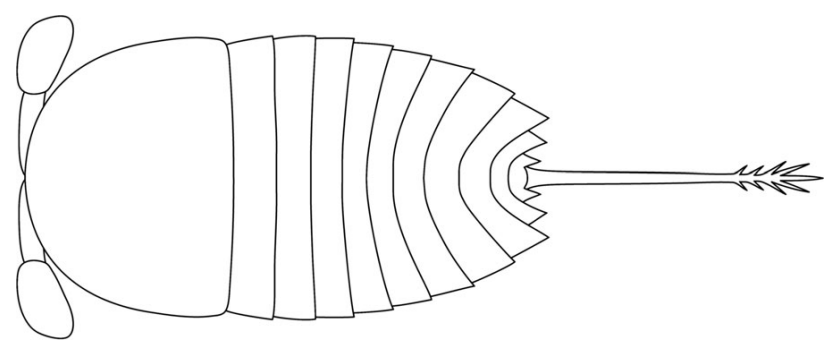

Figure 2. Schematic drawing of Sarotrocercus oblitus Whittington, 1981 based on the present investigation; dorsal view.

such darker areas. We do not interpret them as true articulating structures, but as preservational artifacts. In consequence, the anterior tergites are interpreted as having a rather straight anterior and posterior margin in dorsal view, while the tergite is dorso-ventrally arched. The slightly rounded-appearing rims in some specimens are interpreted as effects of oblique embedding. The more posterior tergites have a rounded anterior and posterior rim, i.e., the tergopleurae curve backwards.

(iii of Whittington 1981) The number of body segments differs from that stated in the original description. Most important is the finding of ontogenetic change in this character, i.e., the presence of at least two developmental stages in the material at disposal. Whittington (1981) probably could not see the tiny posterior structures without applying polarized light. The element behind the last segment (in Whittington's counting number 9; our number 10 in stage II, and 9 in stage I) is not simply cylindrical as originally described, but bears two posterior projections, remnants of tergopleurae. Accordingly this is interpreted as the existence of an eleventh body segment (the $10^{\text {th }}$ in stage I). The terminal body element behind the eleventh segment is interpreted as the telson, which is drawn out into a long spine. Whittington (1981) interpreted the last body segment (in fact, two last segments according to our observation) as the telson, and the spine as being articulated against what he called telson. However, a telson fading out in a spine is rather common among arthropods (e.g., Haug et al. 2009). Again, the presence of tergopleurae indicates the segment character of the element interpreted here as the eleventh body segment in stage II. In other animals possessing a terminal spine, such as aglaspidids, synziphosurans, chasmataspids, eurypterids or Burgessia bella Walcott, 1912, the small element from which the terminal spine arises is usually also interpreted as a true body segment. Thus, the number of body segments is not nine, as originally described, but eleven in stage II (ten in stage I).

(v of Whittington 1981) Whittington (1981) interpreted all visible limb elements as belonging to a single long appendage with seven articles. This interpretation was based on only one specimen (USNM 272151, his figs 90,91). Yet he depicted two specimens in his drawings (his figs 95
[USNM 272151], 97 [USNM 272194]). Our re-study demonstrated that these two specimens have well-preserved appendages on the head. Under polarized light the visible elements indeed appear not to form a continuous limb, but rather represent two different limbs. This view is supported by the second specimen with preserved limbs (USNM 272194; Fig. 3B), where clearly two limbs are present, both with four visible articles. When looking at the supposed single limb on specimen USNM 272151 (Fig. 3A) in a similar way it becomes evident that these limbs do not possess more than four articles. Additionally, small structures bearing three distal setae and associated with these limbs are here interpreted as exopods. Based on the position of the limbs these are interpreted as post-antennular, i.e., appendages two and three. However, a true antennula could not be identified, although it should, of course, be present.

As a consequence of the presence of well-developed endopods in the head limbs also the morphology of the trunk limbs must be reconsidered as similarly having possessed an endopod and exopod. The reconstructed lamellate appendages of Whittington (1981) bear some resemblance to "normal" exopods as developed at the level of Euarthropoda ( $c f$. Haug et al. accepted a) - a conclusion also drawn by Boxshall (2004, see below). Entire limbs resembling such an exopod and being of comb shape are unknown from any other arthropod. Such lamellate structures are only preserved in a single specimen and lack sufficient detail to conclude such an unusual morphology. Especially the likewise unusual reconstructed orientation of the supposed lamellate limbs as drawn in Whittington's (1981) reconstruction (his fig. 131; often reproduced, $c f$. synonymy list) as well as the supposed absence of an endopod cannot be inferred with certainty on such poorly preserved material.

Interestingly, also for another Burgess Shale arthropod, Yohoia tenuis Walcott, 1912, the posterior trunk limbs were reconstructed by Whittington (1974) as consisting only of the exopod part, lacking an endopod. Re-reinvestigation of $Y$. tenuis (Haug et al. accepted b) supports, however, older interpretations by Simonetta \& Delle Cave (1975) in that the trunk limbs possess well-developed endopods (as do the three post-antennal cephalic limbs), but which are usually concealed by the exopods. In consequence, a similar effect can explain the shape of the limbs in S. oblitus. It still cannot be entirely excluded that trunk limb endopods were missing, but the available material offers no evidence for such an absence. Accordingly, following the scientific principle of Ockham's razor, we therefore regard it most plausible that there were endopods, concealed to us because being concealed by their inward folded exopods.

In consequence, the segmental situation and the limb morphology of S. oblitus shows up as much more "normal" than originally assumed. However, this has significant 

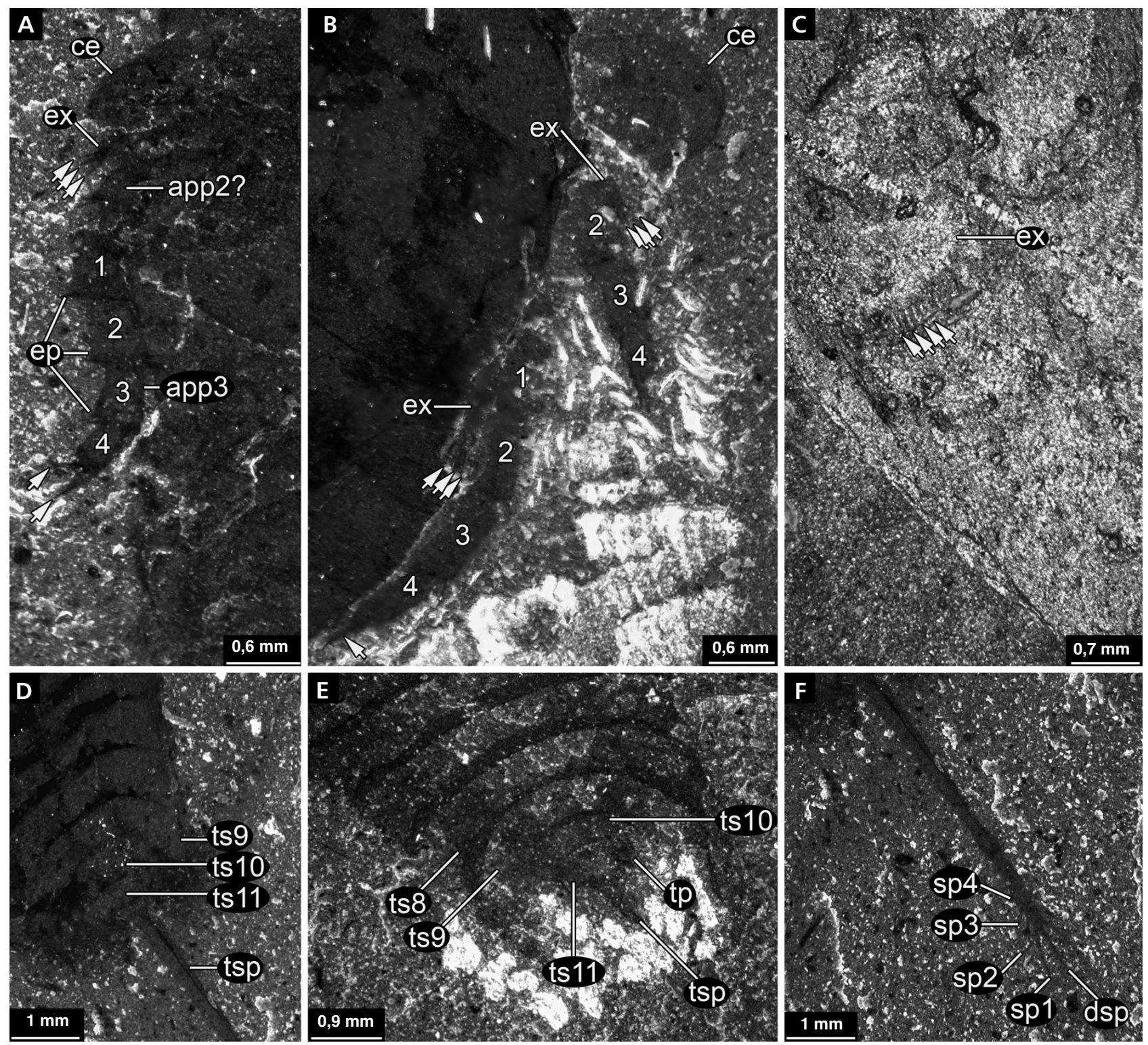

Figure 3. Details of Sarotrocercus oblitus Whittington, 1981. A - USNM 272151. Stage I. Details of cephalic appendages. B - USNM 272194. Stage II. Details of cephalic appendages. $\bullet$ C - USNM 275539. Stage II. Details of trunk appendages. $\bullet$ D - USNM 272171 . Stage II. Detail of trunk end with the smaller crescent-shaped segments. $\bullet$ E - USNM 272133. Stage II. Detail of trunk end with apparent tergopleurae. $\bullet$ F - USNM 272171. Stage II. Details of the distal end of the tail spine with spinules. Abbreviations other than before: $1-4-$ visible articles of the appendages; app2? - possible second appendage; app3 - third appendage; dsp - distal spinule; ep - enditic protrusion; ex - exopod; tp - tergopleura; ts8-11 - trunk segments 8-11; tsp - terminal spine; sp1-4 - spinules 1-4. Arrows mark endopod and exopod setae.

consequences on previous assumptions about the evolutionary impact of S. oblitus.

\section{Systematic and evolutionary implications of Sarotrocercus oblitus: Former ideas}

Wills et al. (1994, 1995, 1998), but also later investigations based on their studies (e.g., Sutton et al. 2002) included Sarotrocercus oblitus in their phylogenetic analyses, coding the species according to Whittington's (1981) reconstruction. Fryer (1999) heavily criticized the way of handling S. oblitus in such analyses. He pointed out that only if certain key features are present in imperfectly preserved fossils it is possible to reach a confident phylogenetic placement. In other cases the result would inevitably be illogical placements. The latter seems to have been the case for S. oblitus, because, as Fryer (1999) pointed out, it was usually placed with different species that appeared to have nothing in common with S. oblitus. Yet despite the 
apparently incomplete knowledge and difficulty to place $S$. oblitus somewhere in the arthropod phylogenetic tree, the species gained much attention ( $c f$. synonymy list) and was used, since its description, for reconstructing quite a number of evolutionary scenarios.

One aspect of the imperfect preservation is that it has led to evolutionary interpretations of the supposed "lamellate" limbs. Schram \& Koenemann (2001) compared the lamellate appendages described by Whittington (1981) with the special developmental mode of eubranchiopod appendages ( $c f$. Olesen 2007). They obviously accepted the interpretation that the preserved part represents the complete limbs and did not state if it includes both endopod and exopod. Boxshall (2004) interpreted the morphology slightly differently from the original idea of Whittington (1981) in citing Sarotrocercus oblitus as one of the rare examples of a loss of endopods. We agree with Boxshall (2004) that what is preserved of the limb is best interpreted as an exopod. The absence of an endopod may better be interpreted as a result of preservation instead of assuming an evolutionary reduction (see above).

Also the body tagmatization of Sarotrocercus oblitus was used for evolutionary interpretations. Minelli (2001), for example, cited $S$. oblitus as an example of animals with so-called "undivided eo-segments" - being 13 according to Minelli's theory. As we could demonstrate above, $S$. oblitus had indeed not only nine trunk segments, but eleven plus the ocular and at least three appendage-bearing head segments, making up a total of at least 15 segments plus the non-somitic telson. Consequently, Minelli's (2001) interpretation of S. oblitus possessing 13 undivided "eosegments" must be rejected - independent from any judgement of the value of the "eosegment" idea, which cannot be discussed here.

\section{Systematic and evolutionary implications of Sarotrocercus oblitus: New interpretation}

Based on its original description, Sarotrocercus oblitus appeared to be a good candidate for representing an offshoot of the evolutionary lineage between Arthropoda s. str. and Euarthropoda. This assumption was based on its head with only few segments and the limb-like first antennula. Even though the antennula turned out to be two misinterpreted post-antennular limbs and the head includes more segments than originally described, S. oblitus is interpreted as a derivative of the lineage towards Euarthropoda above the evolutionary level of fuxianhuiids.

In this context, the absence of the antennulae in all specimens at hand is very important. This indicates probably a very small size of this appendage, a character most likely secondarily evolved, i.e., autapomorphic for Saro- trocercus oblitus. In the ground pattern of Arthropoda $s$. str. as well as in the ground pattern of Euarthropoda the prominent antennulae comprised 15 articles [(examples from Euarthropoda: Agnostus pisiformis (Wahlenberg, 1818), see Müller \& Walossek (1987); certain anomalocarids, cf. Chen et al. (2004); Kiisortoqia soperi Stein, 2010, see Stein (2010)].

Another important aspect is that the endopods of limbs two and three appear to be composed of few articles with enditic protrusions and spines and that these limbs possess a flap-shaped exopod with marginal setation. According to Maas et al. (2004) (see also Waloszek et al. 2005, 2007; Haug et al. accepted a) these characters first appear in the ground pattern of Euarthropoda, but are not yet present in the ground pattern of Arthropoda s. str. Maas et al. (2004) have already pointed to a stepwise acquisition of characters along the lineage towards Euarthropoda, exemplified by the morphology of the taxon Canadaspis. However, the different interpretations of the Chinese and the Canadian species of Canadaspis (Briggs 1978 vs. Hou \& Bergström 1997) demand for a reinvestigation of this material. Sarotrocercus oblitus is now the first definite example for a species possessing only some of the characters formerly interpreted as autapomorphies of Euarthropoda. A character not yet evolved in S. oblitus, but just in the ground pattern of Euarthropoda, is the fourth appendage-bearing segment being included into the head. A character that remains controversial for S. oblitus is the presence or absence of a basipod with enditic protrusions along the median edge together with the basipod-body joint with a prominent membrane. Regardless of the presence or absence of a basipod, the endopod of $S$. oblitus appears to possess relatively few elements compared to the ground pattern of Arthropoda $s$. str. and also Euarthropoda (Haug et al. accepted a). Such a condition could be interpreted as an autapomorphy.

All these facts point to a sister-group relationship of Sarotrocercus oblitus and Euarthropoda. Further taxa, which might have branched off the evolutionary lineage towards Euarthropoda before or after S. oblitus, still need to be reinvestigated with a focus on the characters discussed here.

\section{Life habits of Sarotrocercus oblitus}

The life habits of Sarotrocercus oblitus can, of course, only be estimated, with the reconstruction based on what is known of its morphology. Whether it was indeed swimming on its back as depicted by Whittington (1981) and often reproduced (compare synonymy list) remains unclear, but is plausible for such small animals. Yet, S. oblitus was probably not swimming high up in the water column as sometimes shown, but closer to the bottom. Also a benthic mode of life cannot be excluded. Due to the supposed small 


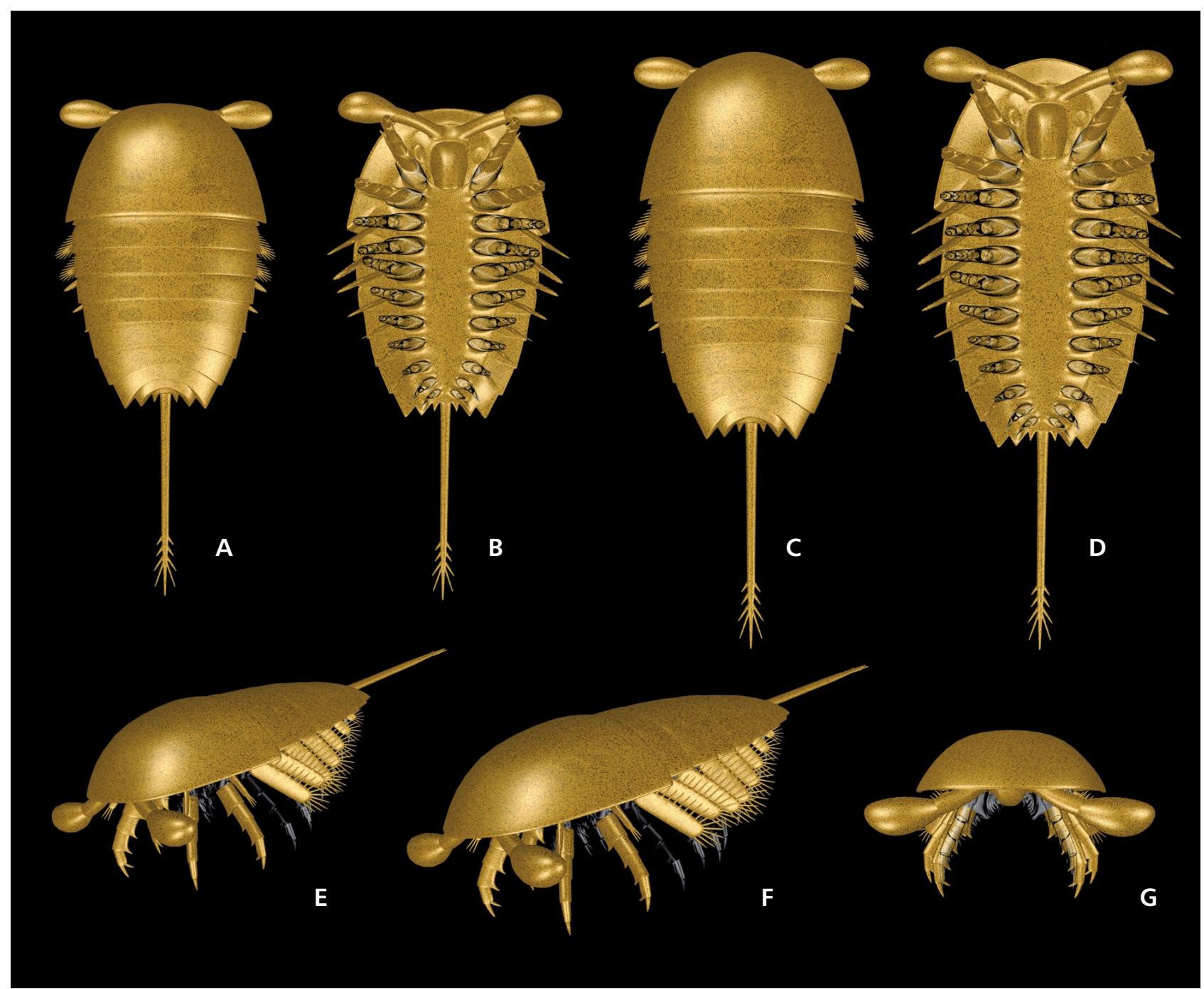

Figure 4. 4D model of Sarotrocercus oblitus Whittington, 1981. • A, B, E - stage I. • C, D, F, G - stage II. • A, C - dorsal view. B, D - ventral view. $\mathrm{E}, \mathrm{F}-$ oblique antero-dorso-lateral view. $\bullet \mathrm{G}-$ anterior view. Both stages to the same scale. Questionable details depicted as transparent black.

size of the antennulae the animal would indeed possess special life habits, using mainly the second and third appendage for feeding. Both have prominent endopods with median armament and are well equipped for this purpose. Also the orientation of these appendages points to their use as raking or grasping devices instead of being functional walking legs.

Sarotrocercus oblitus distantly reminds of the Cambrian crustacean Henningsmoenicaris scutula (Fig. 5; for a recent reinvestigation of $H$. scutula see Haug et al. 2010). The largest stage of $H$. scutula probably measured $2.5 \mathrm{~mm}$ (Schoenemann et al. submitted), which means that this species is significantly smaller than S. oblitus, but still in a similar order of magnitude. H. scutula also possesses stalked eyes protruding from underneath the shield, but stalked eyes are already part of the ground pattern of Arthropoda sensu stricto. Furthermore, the eyes of $H$. scutula have differentiated optical areas within the eyes, which is also visible in the shape of the eyes in older developmental stages (Castellani et al. accepted, Schoenemann et al. submitted). The simple bulbous shape of the eyes of S. oblitus is also found in H. scutula in smaller sized specimens of about one millimeter size. As H. scutula has more appendage-bearing segments included into the head than S. oblitus (five instead of three), but fewer segments in the trunk (ten instead of eleven), both species have about the same number of segments. In both species the second and third appendages have specialized exopods. Yet, they are large and multi-annulated in H. scutula, but tiny paddles in S. oblitus. Also the telson is only superficially comparable. In $H$. scutula it bears five spines, while in S. oblitus there are nine. Additionally, the telson in H. scutula is only slightly drawn out, not extending into a long spine.

A major difference between the two species is the 


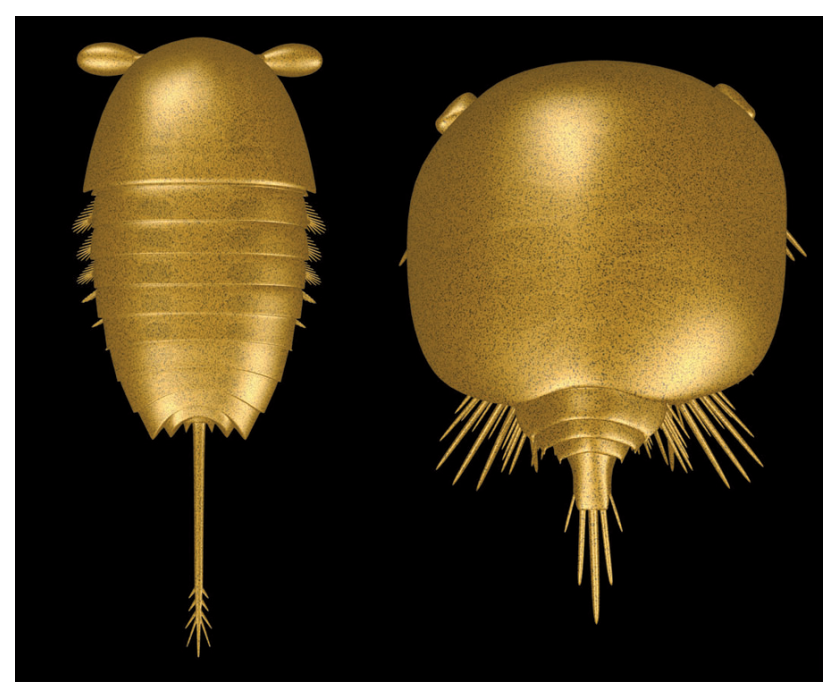

Figure 5. 3D models for comparison of Sarotrocercus oblitus Whittington, 1981 (left) and Henningsmoenicaris scutula (Walossek \& Müller, 1990) (right) in dorsal view.

antennular morphology. The antennulae are huge in Henningsmoenicaris scutula, in which they were probably the main food-sweeping organs, while they must have been tiny (or secondarily absent) in Sarotrocercus oblitus. Also the general tagmatization differs significantly. In $\mathrm{H}$. scutula the animal is almost entirely covered by the large, bowl-shaped head shield. While the general shape, although slightly more elongated in anterior-posterior axis, is comparable to that in S. oblitus, in the latter mainly the tergites of the trunk segments cover the body.

\section{Conclusions}

The morphology of the tiny arthropod Sarotrocercus oblitus from the Burgess Shale differs, according to our re-study, significantly from that outlined in previous descriptions in that:

(i) the head comprises probably three appendage-bearing segments;

(ii) the absence of antennulae protruding beyond the head shield indicates that the antennulae were probably small;

(iii) head appendages two and three are biramous and possess a well-developed endopod but comprising only four visible articles, and a small exopod;

(iv) the number of trunk segments is eleven in the oldest known stage, but it remains unclear whether this is the adult condition;

(v) the trunk limbs possess well-developed paddleshaped exopods with marginal setation, but probably due to preservational aspects no data are available on endopods; their presence is only assumed.
Newly observed is furthermore that the proximal three endopodal articles of the second and third appendages bear short enditic protrusions and spines. The occurrence of at least two different developmental stages in the existing material of the species could be documented. The differences are apparent in overall length and a different number of trunk segments: ten in stage I and eleven in stage II. However, it remains open if this was the final number achieved by the species.

Based on the newly observed features it is likely that Sarotrocercus oblitus is not an in-group representative of Euarthropoda. It is a definite representative of Arthropoda sensu stricto that shares certain features with Euarthropoda, such as the setation and enditic protrusions of the endopod, but probably branched off below the node of Euarthropoda. This could help to reconstruct the stepwise acquisition of characters along the evolutionary lineage towards modern arthropods.

\section{Acknowledgements}

We thank Douglas Erwin, Jann Thompson and Mark Florence from the National Museum of Natural History of the Smithsonian Institution, Washington, D.C., for their kind assistance with the collection of the Burgess Shale animals. Jan Bergström, Stockholm, and Petr Budil, Prague, gave helpful comments on the manuscript. We also thank all people involved in programming open source/open access software that was used in this study, namely CombineZM, Gimp, OpenOffice, Blender. JTH was kindly funded by the German Research Foundation (DFG, Wa 754/15-1) and is currently supported by the Alexander von Humboldt-Foundation with a Feodor Lynen Research Fellowship.

\section{References}

Barnes, R.S.K., Calow, P., Olive, P.J.W., Golding, D.W. \& SPICER, J.I. 2001. The Invertebrates - A Synthesis. Third Edition. 505 pp. Blackwell Science Ltd. Malden, Oxford, Melbourne, Berlin.

Barton, N.H., Briggs, D.E.G., Eisen, J.A., Goldstein, D.B. \& Patel, N.H. 2007. Evolution. 834 pp. Cold Spring Harbor Laboratory Press, Cold Spring Harbor, New York.

Bengtson, S. 2000. Teasing fossils out of shales with cameras and computers. Palaeontologia Electronica 3(1), art. 4, 14 pp., http://palaeo-electronica.org/2000_1/fossils/issue1_00.htm.

Boxshall, G.A. 2004. The evolution of arthropod limbs. Biological Reviews 79, 253-300. DOI 10.1017/S1464793103006274

Briggs, D.E.G. 1978. The morphology, mode of life, and affinities of Canadaspis perfecta (Crustacea: Phyllocarida), Middle Cambrian, Burgess Shale, British Columbia. Philosophical Transactions of the Royal Society of London B 281, 439-487. DOI 10.1098/rstb.1978.0005

BRigGs, D.E.G. \& Collins, D. 1999. The arthropod Alalcome- 
naeus cambricus Simonetta, from the Middle Cambrian Burgess Shale of British Columbia. Palaeontology 42(1), 953-977. DOI 10.1111/1475-4983.00104

Briggs, D.E.G., Erwin, D.H. \& Collier, F.J. 1994. The Fossils of the Burgess Shale. 238 pp. Smithsonian Institution Press, Washington, London.

Briggs, D.E.G. \& Fortey, R.A. 1992. The Early Cambrian radiation of arthropods, 335-373. In LipPS, J.H. \& SignoR, P.W. (eds) Origin and Early Evolution of the Metazoa. Plenum Press, New York.

BuDD, G.E. 2001. Ecology of nontrilobite arthropods and lobopods in the Cambrian, 404-427. In ZhuRAvLEv, A.Y. \& Riding, R. (eds) Ecology of the Cambrian Radiation. Columbia University Press, New York.

BudD, G.E. 2008. Head structure in upper stem-group euarthropods. Palaeontology 51(3), 561-573. DOI 10.1111/j.1475-4983.2008.00752.x

Burzin, M.B., Debrenne, F. \& Zhuravlev, A.Y. 2001. Evolution of shallow-water level-bottom communities, 217-237. In ZHURAVLEV, A.Y. \& RiDING, R. (eds) Ecology of the Cambrian Radiation. Columbia University Press, New York.

CARon, J.-B. \& JACKSON, D.A. 2008. Paleoecology of the Greater Phyllopod Bed community, Burgess Shale. Palaeogeography, Palaeoclimatology, Palaeoecology 258(3), 222-256. DOI 10.1016/j.palaeo.2007.05.02

Castellani, C., Haug, J.T., Haug, C., Maas, A., Schoenemann, B. \& WALOSZEK, D. accepted. Exceptionally well-preserved isolated eyes from late Cambrian 'Orsten' faunal assemblages of Sweden. Palaeontology.

Chen, J.-Y., Waloszer, D. \& MaAs, A. 2004. A new 'great-appendage' arthropod from the Lower Cambrian of China and homology of chelicerate chelicerae and raptorial antero-ventral appendages. Lethaia 37, 3-20.

DOI 10.1080/00241160410004764

Cotton, T.J. \& BRADDY, S.J. 2004. The phylogeny of arachnomorph arthropods and the origin of Chelicerata. Transactions of the Royal Society of Edinburgh: Earth Sciences 94, 169-193.

Delle Cave, L., Insom, E. \& Simonetta, A.M. 1998. Advances, diversions, possible relapses and additional problems in understanding the early evolution of the Articulata. Italian Journal of Zoology 65, 19-38. DOI 10.1017/S0263593300000596

Dewel, R.A. \& Dewel, W.C. 1998. The place of tardigrades in arthropod evolution, 109-124. In ForTEY, R.A. \& THOMAs, R.H. (eds) Arthropod Relationships. The Systematics Association Special Volume Series 55. Chapman \& Hall, London.

FRYER, G. 1998. A defence of arthropod polyphyly, 23-34. In Fortey, R.A. \& Thomas, R.H. (eds) Arthropod Relationships. The Systematics Association Special Volume Series 55. Chapman \& Hall, London.

FRYER, G. 1999. Cambrian animals: evolutionary curiosities or the crucible of creation? Hydrobiologia 403, 1-11. DOI 10.1023/A:1003799411987

Gould, S.J. 1991a. Zufall Mensch. 391 pp. Carl Hanser Verlag, München, Wien. [English original 1989. Wonderful Life: The Burgess Shale and the Nature of History. W.W. Norton, New York]

Gould, S.J. 1991b. The Disparity of the Burgess Shale arthropod fauna and the limits of cladistic analysis: why we must strive to quantify morphospace. Paleobiology 17(4), 411-423. DOI $10.2307 / 2400754$

Gould, S.J. 1994. The evolution of life on Earth. Scientific American, 1994(October), 92-100.

Gould, S.J. 1999. The evolution of life, 1-14. In Schopf, J.W. (ed.) Evolution! Facts and Fallacies. Academic Press, San Diego.

Haug, J.T., MaAs, A. \& Waloszek, D. 2009. Ontogeny of two Cambrian stem crustaceans, †Goticaris longispinosa and $\uparrow$ Cambropachycope clarksoni. Palaeontographica, Abteilung A 289, 1-43.

Haug, J.T., MaAs, A. \& Waloszek, D. 2010. †Henningsmoenicaris scutula, †Sandtorpia vestrogothiensis gen. et sp. nov. and heterochronic events in early crustacean evolution. Earth and Environmental Science Transactions of the Royal Society of Edinburgh 100, 311-350. DOI 10.1017/S1755691010008145

Haug, J.T., MaAs, A., Haug, C. \& Waloszek, D. accepted a. Chapter 2: Evolution of Crustacean Appendages. In WATLING, L. \& THIEL, M. (eds) The Natural History of the Crustacea. Volume 1: Functional Morphology and Diversity. Oxford University Press.

Haug, J.T., Waloszek, D., MaAs, A., Liu, Y. \& Haug, C. accepted b. Functional morphology, ontogeny and evolution of mantis shrimp-like predators in the Cambrian. Palaeontology.

Hou, X. 1987. Two new arthropods from Lower Cambrian Chengjiang, Eastern Yunnan. Acta Palaeontologica Sinica 26, 236-256.

Hou, X. \& Bergström, J. 1997. Arthropods of the Lower Cambrian Chengjiang fauna, southwest China. Fossils and Strata $45,1-116$.

LiN, J. 2009. Function and hydrostatics in the telson of the Burgess Shale arthropod Burgessia. Biology Letters 5(3), 376-379. DOI 10.1098/rsbl.2008.0740

Liu, Y., Hou, X. \& BergströM, J. 2007. Chengjiang arthropod Leanchoilia illecebrosa (Hou, 1987) reconsidered. Geologiska föreningens i Stockholm förhandlingar 129, 263-272. DOI 10.1080/11035890701293263

Maas, A., Waloszek, D., Chen, J., Braun, A., Wang, X. \& Huang, D. 2004. Phylogeny and life habits of early arthropods - predation in the Early Cambrian sea. Progress in Natural Science 14, 158-166.

DOI 10.1080/10020070412331343301

MinelLi, A. 2001. A three-phase model of arthropod segmentation. Development Genes and Evolution 211, 509-521. DOI $10.1007 / \mathrm{s} 004270100180$

MüLLER, K.J. 1983. Crustacea with preserved soft parts from the Upper Cambrian of Sweden. Lethaia 16, 93-109.

DOI 10.1111/j.1502-3931.1983.tb01704.x

MÜLLER, K.J. \& WALOSSEK, D. 1987. Morphology, ontogeny, and life habit of Agnostus pisiformis from the Upper Cambrian of Sweden. Fossils \& Strata 19, 1-124.

OlesEN, J. 2007. Monophyly and phylogeny of Branchiopoda, with focus on morphology and homologies of branchiopod phyllopodous limbs. Journal of Crustacean Biology 27, 165-183. DOI 10.1651/S-2727.1

Schoenemann, B., Castellani, C., Clarkson, E.N.K., Haug, J.T., MAas, A., HaUg, C. \& WaloszeK, D. submitted. The sophisticated visual system of a tiny Cambrian crustacean - 
analysis of a stalked fossil compound eye. Proceedings of the Royal Society of London B.

Scholtz, G. \& EDGecombe, G.D. 2006. The evolution of arthropod heads: reconciling morphological, developmental and palaeontological evidence. Development Genes \& Evolution 216, 395-415. DOI 10.1007/s00427-006-0085-4

Schram, F.R. \& Koenemann, S. 2001. Developmental genetics and arthropod evolution: part I, on legs. Evolution \& Development 3(5), 343-354. DOI 10.1046/j.1525-142X.2001.01038.x

Selfa, J. \& Pujade-Villar, J. 2002. Fonaments de zoologia dels artròpodes. 426 pp. Universitat de València, València.

Simonetta, A.M. \& Delle Cave, L. 1975. The Cambrian non Trilobite Arthropods from the Burgess Shale of British Columbia. A study of their comparative taxonomy and evolutionary significance. Palaeontographica Italica 69, 1-37.

Stein, M. 2010. A new arthropod from the Early Cambrian of North Greenland, with a 'great appendage'-like antennula. Zoological Journal of the Linnean Society 158, 477-500. DOI 10.1111/j.1096-3642.2009.00562.x

Stein, M., WaloszeK, D., MaAs, A., Haug. J.T. \& Müller, K.J. 2008. Oelandocaris oelandica revisited. Acta Palaeontologica Polonica 53, 461-484.

Sutton, M.D., Briggs, D.E.G., Siveter, D.J., Siveter, D.J. \& ORR, P.J. 2002. The arthropod Offacolus kingi (Chelicerata) from the Silurian of Herefordshire, England: computer based morphological reconstructions and phylogenetic affinities. Proceedings of the Royal Society of London B 269, 1195-1203. DOI 10.1098/rspb.2002.1986

VAN Roy, P. 2006. An aglaspidid arthropod from the Upper Ordovician of Morocco with remarks on the affinities and limitations of Aglaspidida. Transactions of the Royal Society of Edinburgh Earth Sciences 96, 327-350.

Wahlenberg, G. 1818. Petrificata telluris svecanae. Nova Acta Regiae Societatis Scientiarum Upsaliensis 8, 1-116.

Walcott, C.D. 1912. Middle Cambrian Branchiopoda, Malacostraca, Trilobita and Merostomata. Cambrian Geology and Paleontology II. Smithsonian Miscellaneous Collections 57, $145-228$.
WalosseK, D. 1999. On the Cambrian diversity of Crustacea. Pages 3-27. In Schram, F.R. \& VAupel KLein, J.C. von (eds) Crustaceans and the Biodiversity Crisis, Proceedings of the Fourth International Crustacean Congress, Amsterdam, The Netherlands, July 20-24, 1998, vol. 1. Brill Academic Publishers, Leiden, The Netherlands.

WalosseK, D. \& MÜLleR, K.J. 1990. Upper Cambrian stem-lineage crustaceans and their bearing upon the monophyletic origin of Crustacea and the position of Agnostus. Lethaia 23, 409-427. DOI 10.1111/j.1502-3931.1990.tb01373.x

WaloszeK, D., Chen, J., MaAs, A. \& WANG, X. 2005. Early Cambrian arthropods-new insights into arthropod head and structural evolution. Arthropod Structure and Development 34, 189-205. DOI 10.1016/j.asd.2005.01.005

Waloszek, D., Maas, A., Chen, J.-Y. \& Stein, M. 2007. Evolution of cephalic feeding structures and the phylogeny of Arthropoda. Palaeogeography, Palaeoclimatology, Palaeoecology 254, 273-287. DOI 10.1016/j.palaeo.2007.03.027

WhitTington, H.B. 1974. Yohoia Walcott and Plenocaris n. gen., arthropods from the Burgess Shale, Middle Cambrian, British Columbia. Geological Survey of Canada, Bulletin 231, 1-63.

Whittington, H.B. 1981. Rare Arthropods from the Burgess Shale, Middle Cambrian, British Columbia. Philosophical Transactions of the Royal Society of London, Series B, Biological Sciences 292(1060), 329-357.

Wills, M.A., Briggs, D.E.G. \& Fortey, R.A. 1994. Disparity as an Evolutionary Index: A Comparison of Cambrian and Recent Arthropods. Paleobiology 20(2), 93-130. DOI $10.2307 / 2401014$

Wills, M.A., Briggs, D.E.G., Fortey, R.A. \& Wilkinson, M. 1995. The significance of fossils in understanding arthropod evolution. Verhandlungen der Deutschen Zoologischen Gesellschaft 88, 203-215.

Wills, M.A., Briggs, D.E.G. \& Fortey, R.A. 1998. Evolutionary correlates of arthropod tagmosis: scrambled legs, 57-66. In ForTey, R.A. \& ThOMAs, R.H. (eds) Arthropod Relationships. The Systematics Association Special Volume Series 55. Chapman \& Hall, London. 